\title{
Emotional Intelligence and Undergraduate Engineering Students
}

\author{
Charles Skipper ${ }^{1 *}$, Lindsay Greenlee ${ }^{2}$, Jannette Finch ${ }^{3}$, and Kaitlin Marley ${ }^{4}$
}

\begin{abstract}
Engineers in construction and manufacturing are expected to be able to work with and lead diverse, multidisciplinary teams. Engineering students entering the workforce must be not only technically competent, but also possess skills in working with other people. These traits are frequently lacking with newly graduated engineering students due to the highly technical focus of their curriculum. The opportunity to develop Emotional Intelligence skills is limited. This research proposed that Civil and Environmental Engineering (CEE) undergraduate students may possess a higher level of Emotional Intelligence than Electrical and Computer Engineering (ECE) undergraduate students. The research also proposed that if differences were observed, that causal influences could be identified. Undergraduate engineering students at The Citadel completed The TalentSmart Emotional Intelligence Appraisal@ along with demographic data and a variety of questions regarding their undergraduate experience. This research included freshman and senior students in Civil and Environmental (CEE) and Electrical and Computer Engineering (ECE) at The Citadel. These surveys suggested that undergraduate engineering students increase their EI score as they advance from Freshman to Senior year. The surveys also suggest that Electrical and Computer Engineering (ECE) Majors do not advance in their EI scores from Freshman to Senior year as well as Civil and Environmental (CEE) majors. A positive connection was established between work experience and the impact on higher levels of EI. A positive correlation for growth in EI score was also demonstrated for students who attended high schools with smaller graduating classes. Based on the results of this research, the paper proposes CEE and ECE faculty place increased emphasis on encouraging students to pursue summer jobs, internships, and similar extracurricular programs. Both CEE and ECE faculty should evaluate their curriculum with an eye towards inculcating learning opportunities for EI into course work. Additionally, faculty and admission officials should give at least equal consideration to admitting students who graduate from smaller schools that may offer less college prep courses that may appeal to admissions officials.
\end{abstract}

\section{Keywords}

Leadership, Emotional Intelligence, Undergraduate Students

\footnotetext{
${ }^{1}$ Department of Engineering Leadership \& Program Management, The Citadel, Charleston, SC $29409 *$ Corresponding Author: E-mail: skipperc1@ citadel.edu

${ }^{2}$ Department of Psychological Sciences, Texas Tech University, Lubbock, TX 79409 lindsay.greenlee@ttu.edu

${ }^{3}$ Lowcountry Graduate Center, College of Charleston, Charleston, SC 29405 finchj@ cofc.edu

${ }^{4}$ University of California-San Diego, La Jolla, CA 92093 kaitlinmarley@gmail.com
} 
relationship between emotional intelligence

\section{Introduction}

Engineering, like most professions, has unique features. Students who graduate with engineering degrees are virtually ensured of well-paying jobs upon graduation, and a solid career in an honorable and respected field. In return for those advantages, they must meet a very demanding undergraduate curriculum. Typically engineering students take more hours than most other majors, have more graded homework assigned on a regular basis, and are required to meet specific measurable requirements on tests vice the opinions and interpretations that are prevalent in many other majors. The gauntlet that engineering students must endure of chemistry, calculus, physics, and engineering problem solving courses may not be conducive to free thinkers, or students who are highly focused on people and their feelings as opposed to delivering numerical responses and technical problem solving.

On the other hand, upon graduation professional expectations change somewhat. Engineers in construction and manufacturing are expected to be able to work with and lead diverse, multidisciplinary teams. "Construction is a people business. In this business, you are hired for your technical skills, fired for your lack of people skills and promoted for your management skills," (Badger, 2002). In other words, engineering students entering the workforce must be not only technically competent, but also possess skills in working with other people. These traits are not normally associated with newly graduated engineering students (Walesh, 2012).

Emotional intelligence (EI) has become one way to measure non-mathematical/people oriented interests as a relevant indicator of performance in the workforce. Research on the importance and relevance of the and performance began in the mid-1990s, and is continuing (Goleman, 1995). Technical expertise is simply not enough for real success for engineering graduates. Employers are looking for engineering graduates who will be able to remain technically competent in a quickly changing world while also being people oriented leaders and teammates who can attain great results on the job. The wellknown phrases for "soft skills" are leadership and emotional intelligence. They are now viewed as effective means to identify possible high-performance workers (Mayer and Geher, 1996). Figure 1 reports the 5 EI competencies as proposed by Goleman, grouped into two main categories: personal skills and social skills.

The purpose of this research was two-fold; first to determine if there was a difference between the EI scores of Civil and Environmental Engineering (CEE) students and Electrical and Computer Engineering (ECE) students, as measured by The TalentSmart Emotional Intelligence Appraisal ${ }^{\circledR}$. Second, to determine if there were life influences that impact the differences in the EI scores. At the time this research was conducted, CEE and ECE were the only engineering majors available for research. It is posed that higher emotional intelligence is at least a partial product of the academic curriculum of these two different majors, as well as the pre and during college experiences. Some researchers believe that Emotional Intelligence can be worked into the undergraduate engineering curriculum, just like any other important skill set that is a desired outcome (Bradberry and $\mathrm{Su}, 2009$ ). To evaluate Emotional Intelligence, "The Emotional Intelligence Appraisal(C), a skillbased self-reporting measure of emotional intelligence was utilized. This assessment was chosen because of its ease of collection and ability to further analyze data that is generated (Bradberry and Su, 2003). Students were also 
asked to complete a supplementary questionnaire that was used to collect information on student demographics, work experiences, number and size of high schools attended, and other potential Emotional Intelligence influences.

\begin{tabular}{|c|c|}
\hline \multicolumn{2}{|c|}{ Personal Skills (how we manage ourselves) } \\
\hline $\begin{array}{l}\text { Self- } \\
\text { Awareness }\end{array}$ & $\begin{array}{l}\text { Knowing one's internal states, } \\
\text { preferences, resources, and } \\
\text { intuitions. Recognizing ones } \\
\text { emotions and their effects, } \\
\text { strengths, limits, self-worth. }\end{array}$ \\
\hline $\begin{array}{l}\text { Self- } \\
\text { Regulation }\end{array}$ & 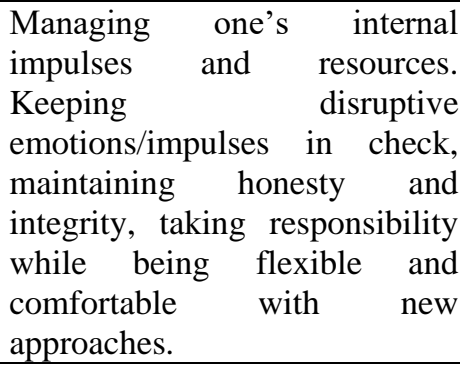 \\
\hline Motivation & $\begin{array}{l}\text { Emotional tendencies that guide } \\
\text { or facilitate reaching goals. } \\
\text { Striving to improve, aligning } \\
\text { with goals of the group, acting } \\
\text { on opportunities and persisting } \\
\text { while overcoming obstacles. }\end{array}$ \\
\hline \multicolumn{2}{|r|}{ Social Skills } \\
\hline Empathy & $\begin{array}{l}\text { Awareness of other's feelings } \\
\text { needs and concerns. Sensing, } \\
\text { others' feelings, needs, } \\
\text { concerns. Anticipating and } \\
\text { recognizing the needs. } \\
\text { Cultivating opportunities and } \\
\text { reading a group's emotional } \\
\text { currents. }\end{array}$ \\
\hline Social Skills & $\begin{array}{l}\text { Adeptness and inducing } \\
\text { desirable responses in others. } \\
\text { Persuasion, communication, } \\
\text { conflict resolution, leadership, } \\
\text { managing change, nurturing } \\
\text { relationships, collaboration, } \\
\text { creating synergy. }\end{array}$ \\
\hline
\end{tabular}

Figure 1. Five EI Competencies (Goleman, 1998)

\section{Literature Review}

A survey of the literature supports the hypothesis that Emotional Intelligence (EI) would increase from Freshman to Senior class level, as research by Boyatzis (2009) and Mo and Dainty (2007) shows that EI increases "relative to age and work experience" (Boyatzis, 2009); (Mo \& Dainty, 2007).

So what is the value of Emotional Intelligence? The term has appeared in many studies, from 1966 to the present, although Petrides, Frederickson, and Furnham (2004) report that the term as it is used today was introduced by Salovey and Mayer (1990) and became part of the mainstream with Daniel Goleman's popular book, Emotional Intelligence (1995). The classic definition by Salovey and Mayer is "the subset of social intelligence that involves the ability to monitor one's own and other's feelings and emotions, to discriminate among them and to use this information to guide one's thinking and actions" (1990), (Petrides et al., 2004); (Salovey, P. and Mayer, 1990); (Goleman, 2006).

The need for Emotional Intelligence to be applied to engineering students is becoming well represented in the literature as educational institutions realize that employers want to hire graduates who not only possess the technical knowledge of engineering, but perhaps more importantly, possess soft skills. These nontechnical skills allow them to be effective members of a team, interface effectively with the public, and better represent their organization in business settings. Ironically, job interviews for engineers typically focus on soft skills, since all engineering curriculums turn out students who meet the standard technical requirements of The Accreditation Board for Engineering and Technology (ABET). 
"Engineers no longer manage their daily tasks with plain substance expertise; instead they must be adept at communication, collaboration, networking, feedback provision and reception, teamwork, lifelong learning, and cultural understanding... working life skills relevant in today's work communities" (Lappalainen, 2009). Desired attributes that help engineering graduates find jobs include "self-management, business and customer awareness, problem solving, communication and literacy, application of numeracy and information technology, all of which are underpinned by a positive attitude" (Lamb, F., Arlett, C., Dales, R., Ditchfield, B., \& Wakeham, 2010).

For potential employers of engineers, desired candidates ideally possess a combination of academic competence and strong EI skills. A few studies have tried to find correlations between grades and EI. A study published in Engineering Project Organization Journal (Skipper and Brandenburg, 2013) did not find that higher EI contributed to better GPAs. This finding is supported by other research that finds "although the emotional intelligence of students was not directly linked to academic success, those with higher levels of emotional intelligence were more confident that they could handle problems and challenges" (Thilmany, 2005).

One research study reported that Emotional Intelligence is highly associated with the extremely important Project Manager competencies of teamwork, managing conflict, and transformational leadership (Clarke, 2010).

In another study, Leicht, et al. were able to measure the impact of emotional intelligence on the classroom performance of Architectural and Engineering students in an undergraduate course, Introduction to Building Industry. The study found that EQ skills helped to create a higher performing team than predicted by technical skills alone (Leicht, Macht, Riley \& Messner, 2013).

Van der Zee, Thijs and Schakel also find high EI does not predict academic success. The study by these researchers interestingly contrasts self-rated surveys of emotional intelligence with reporting done by others. Some research finds that self-reporting may be inaccurate, and suggest that surveys be supplemented by additional reporting by knowledgeable others, such as peers and spouses (Van der Zee, Thijs, \& Schakel, 2002).

Assessment models of EI can be split into "mixed models" and "ability models." Mixed assessment models have been described as trait-based models and are generally based on self-report. EI measurement based on ability models uses a performance-based response format from which a correct answer can be derived (Bar-on, Reuven, Maree, J.G., and Elias, 2007).

Most common measures of EI use one of the following tests: The Mayer-Salovey-Caruso Emotional Intelligence Test, the Emotional Quotient Inventory, the Emotional Intelligence Scale, the Emotional Competency Inventory, the Emotional Judgement Inventory, or Wong and Law Emotional Intelligence Scale (Bar-on, Reuven, Maree, J.G., \& Elias, 2007).

Using a mixed model tool outside of the commonly used surveys can be supported by leading researchers in the field, who propose that we need to access a wide variety of multidimensional EI assessment instruments that are scientifically developed, normed and validated (Bar-On, R., Maree, J.G., \& Elias, 2007).

In this study, the Emotional Intelligence Appraisal ${ }^{\circledR}$ was employed, which was approved for use by TalentSmart. The Emotional Intelligence Appraisal was selected because scientific data suggests it is an accurate and reliable means of assessing 
emotional intelligence (Skipper \& Brandenburg, 2013). It also can be favorably used in comparison with demographic data to analyze findings.

Other studies using TalentSmart include a large study, a sample size of over thirteen thousand, focusing on project managers and EI (Sunindijo, Hadikusumo, \& Ogunlana, 2007). Also using TalentSmart is a study attempting to correlate EI and academic performance of civil engineering students. This study also finds a positive correlation between work experience and EI (Zhou, 2010).

Lamb, et al. (2010) finds that integration of soft skills into the curriculum is beneficial to students. Internship placement also results in measurable positive attitudes and improved grades (Lamb, F., Arlett, C., Dales, R., Ditchfield, B., \& Wakeham, 2010).

Research conducted by the American Society for Engineering Education (ASEE) describes the ideal employee possessing both deep knowledge of their field and broad knowledge in other areas as "T-Shaped" (American Society for Engineering Education, 2013). The T-Shaped engineer has the deep technical knowledge, skills, and abilities of their profession, balanced with the horizontal bar that includes good communication, persistence, learning capability, high ethical standards critical thinking, and other attributes desired by business.

One study demonstrated the strong connection between emotional intelligence and leadership behaviors of construction leaders (Butler and Chinowsky, 2006). Another study found that Project Managers and Engineers (PMEs) with higher EI scores tended to use more open communication and proactive leadership styles than PMEs with lower EI scores (Sunindijo, Hadikusumo and Ogunlana, 2007). These studies are in line with others that indicate the value of integrating some soft skills education into undergraduate engineering programs.

Once a program recognizes the desirability of cultivating hard and soft skills within the engineering student, several models are suggested in the literature as effective. Many programs advocate for problem-based learning (Butun, Erkin, \& Altintas, 2008), (Cain \& Cocco, 2013) as a preferred pedagogical approach. A 2013 workshop conducted by the American Society for Engineering Education (ASEE) also encourages integrations of problem-based learning into engineering curricula as either course-related work, or as the course itself. Examples of this include club activities, entering competitions (p. 14), design projects for industry, case studies, and internships (p. 6). Dym (2005) finds that Project-based learning integrated into curriculum improves retention, satisfaction, diversity and student learning (Dym, Agogingo, Eris, Frey, \& Leifer, 2005).

Service learning as a pedagogical component which also teaches EI and soft skills is an emerging area strongly advocated for in the literature. Shelby, Ansari, and Patten (2013) describe a freshman engineering course module that teaches students the leadership skills that are essential for them to be exceptional engineers by placing them in team projects servicing real clients (p. 2). Service learning projects integrate real-world experiences, tapping into the proven success of problem-based learning. Shelby et al. find that student engaged in service learning develop the three $\mathrm{Cs}$ of leadership: "competence, compassion, and chronos (time management)" (p. 3). Shelby et al. also find that first year service projects also increase student interest, learning, performance, and retention.

According to the American Society for Engineering Education workshop report, soft skills should be integrated directly in the core engineering curriculum and not be taught in a 
separate course outside of engineering (2013). Additional course work can lead to delayed graduation and students may complain that there is little integration with their engineering major (Lohmann et al., 2006). Many of the strategies for improving emotional intelligence, as proposed by Bradberry and Greaves, can be interwoven directly into engineering curriculum and has the added benefit of being measured for improvement (Bradberry and Greaves, 2009).

Several research studies show potential implications for hiring practices. The candidate possessing the higher EI plus excellent academic knowledge, as revealed through grades, might ensure a better hire (Iannucci, B. and Mirabella, 2013); (Ming Chia, 2005).

Research also supports that Emotional Intelligence, commonly understood as soft skills, can be taught. A major contributor to the field of EI, Reuven Bar-On, has collaborated on many articles on teaching EI through coaching (2007). Research conducted by Jahangard et al. (2012) also finds that EI is a learnable skill, and posits that training of EI components can enhance mental health.

There is comparatively little research in the literature that examines the effect of outside influences such as work experience, social groups, athletics, etc. on engineering education and the growth of emotional intelligence. The above references indicate a need for more study in this area.

\section{Methodology}

The purpose of the current research was to examine possible EI score differences between Civil and Environmental Engineering (CEE) students and Electrical and Computer Engineering (ECE) students. In addition to comparison of scores between majors, and between freshman and seniors, we also sought to examine other factors that may be related to differences in and increases in EI scores. These additionally areas included participation in high school athletics, participation in Junior Reserve Officer Training Corps (JROTC), size and number of schools attended, and part-time and full-time jobs.

This analysis was based on two key assumptions: (1) emotional intelligence can be trained and learned, instead of being totally inherent; and (2) the students involved in this research were promised anonymity and guaranteed that their survey results would not have any reflection on their current academic classes, thereby encouraging the students to answer honestly.

This research included voluntary participation from freshman and senior students in Civil and Environmental Engineering (CEE) and Electrical and Computer Engineering (ECE) at The Citadel. The students were given the assessment during regularly scheduled class periods, and there was no requirement of completion nor was completion incentivized. Students who were not in class on the days surveyed did not participate. The researcher administering the surveys did not have any of the students in his assigned classes, so there was no issue with students being concerned with attempting to satisfy a current professor.

Engineering students at The Citadel, The Military College of South Carolina, follow a standard Accreditation Board for Engineering and Technology (ABET) curriculum. The Citadel was the first College or University in South Carolina to become ABET Accredited, and meeting those education requirements are taken seriously by the faculty and administration. There also is an expectation that all students will complete their studies in 4 years, and most do so. The only significant difference in the academic program from other colleges is that Citadel Students are also 
Table 1. Demographics of Participants

\begin{tabular}{|cc|cc|cc|cc|}
\hline Sex & $\mathrm{N}$ & Year & $\mathrm{N}$ & Major & $\mathrm{N}$ & \multicolumn{2}{|c|}{ Age } \\
\hline Male & 158 & Freshman & 130 & CEE & 103 & Mean & 19.45 \\
Female & 8 & Senior & 36 & ECE & 63 & SD & 2.07 \\
\hline
\end{tabular}

\begin{tabular}{|l|l|}
\hline Major and Year & N \\
\hline Civil Engineering Freshman & 82 \\
\hline Civil Engineering Senior & 21 \\
\hline Electrical Engineering Freshman & 48 \\
\hline Electrical Engineering Senior & 15 \\
\hline
\end{tabular}

required to take 4 years of Reserve Officer Training Corps (ROTC) classes, as well as non-credit instruction on leadership development and ethics.

One hundred and ninety-four students completed The TalentSmart Emotional Intelligence Appraisal ${ }^{\circledR}$. This appraisal has consistently been shown to have high reliability ( $\alpha=0.79$ to $\alpha=0.90$; (TalentSmart, 2011), and consistently, we had high reliability with our sample $(\alpha=0.83)$. Students also completed a supplementary survey that gathered information regarding age, gender, work experiences, athletics, size of their high school, etc. The supplementary questionnaire was developed by the researchers and piloted to several students who were not participants in the research.

The Citadel has a program with the Department of the Navy where high quality enlisted Marines and sailors can attend day classes with Cadets, earn a Bachelor's Degree, and receive a commission as an Officer in the United States Marine Corps or United States Navy. The Citadel also allows Veteran Students, who have completed their military obligation, to attend day classes with the Cadets. These engineering students completed the surveys, but were not included in the analysis since they were older and had substantially more life experience. Our final sample consisted of one hundred and sixty-six students. The majority of the students were male though our sample did include eight female students. Demographics of students participating in the survey are reported in Table 1.

The small sample size of students must be noted. In several areas of the analysis we had relatively small sample sizes, and that prevented the opportunity to have more findings. These small sample sizes were due to the relatively small size of The Citadel (2400 undergraduate students, most of whom do not choose to major in engineering), as well as the drop off in engineering students from entering freshmen to seniors. The authors deleted any discussion or potential findings in those cases where the sample size was too small to be statistically significant.

\section{Results}

In order to examine the differences that civil engineering students have in EI scores from electrical engineering students and to determine differences in the students based on time in school, a simple one-way analysis of variance (ANOVA) was conducted. Due to small sample size of Senior Electrical Engineering Students, this portion of the analysis was limited. Instead the analysis 
looked at results of all freshman and all senior engineering students. To understand how EI scores change during school, we proposed that EI scores would improve from freshman to senior year. A significant result was revealed, $F(2,174)=2.39, \mathrm{p}=.09, \eta_{p}^{2}=.03($ Figure 2$)$.

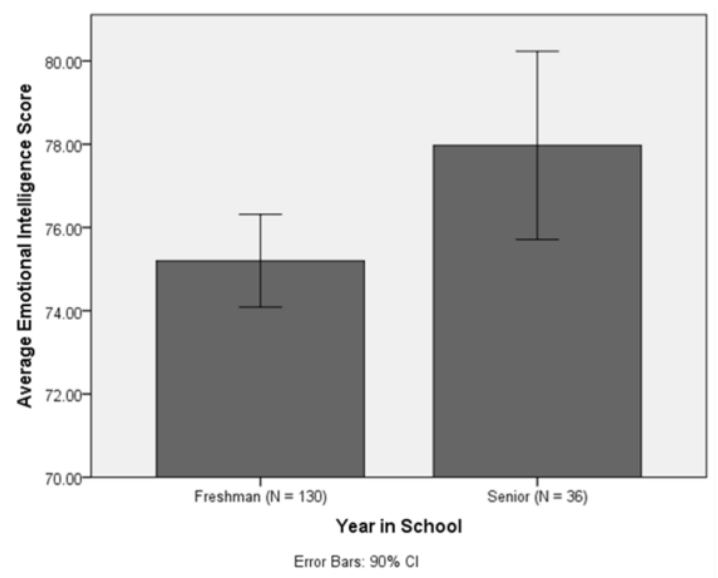

Figure 2. Differences in Emotional Intelligence score by year in school.

To further understand this effect, we examined whether this result was an effect due to schooling or maturation, so a regression analysis was conducted to examine the effect of age on EI scores. A significant effect for age was found, $F(1,163)=5.24, p=.02, R^{2}=$ .03 (Figure 3).

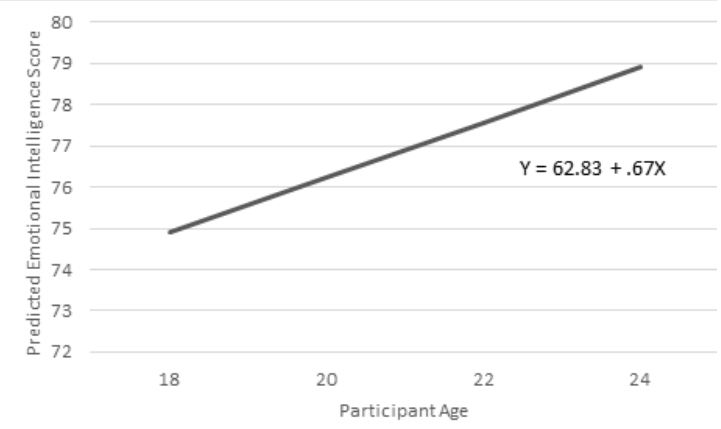

Figure 3. Emotional Intelligence scores as predicted by participant age.
The research utilized a Type I error $\alpha$ value at .10 , which could result in a $90 \%$ degree of confidence in the results of the analysis. The use of a larger p-value in this research was acceptable due to the soft nature of the data being analyzed. This research was exploratory in nature and had a limited sample size.

\section{Life Influences}

One category examined was work experience. Unfortunately, there were too few students with full time work experience of 10 or more months, so the analysis was restricted to parttime work of 10 or more months. The results were available for total seniors and total freshman, but could not be subdivided by major due to the small sample size. An independent samples t-test was used to examine differences in EI scores in those students that had held a part time job for 10 months or more by year in school. As seen in Table 2 below, those seniors that had held lengthy part time work had higher EI scores on average than freshman, $t(55)=2.28, p=.03$.

\begin{tabular}{|l|l|l|l|}
\hline & $N$ & Mean & SD \\
\hline Senior Students & 12 & 79.92 & 7.11 \\
\hline Freshman Students & 44 & 74.41 & 8.55 \\
\hline
\end{tabular}

Table 2. Impact on EI of Part-Time work greater than 10 months.

This result is indicative of the tremendous value for students to have real life work experience. This finding is also supported by previous research that indicated the significant value of work experience in developing Emotional Intelligence (Skipper and Brandenburg, 2013). 
Another category examined was size of high school graduating class. Participants were asked to indicate their estimate of their high school class size. Twenty-two students did not provide an estimate of their high school class size. A regression analysis was used to examine the relationship between high school class size and EI score. Results showed that students with smaller high school classes scored more highly on EI, $F(1,154)=3.51$, p $=.06$ (Figure 4).

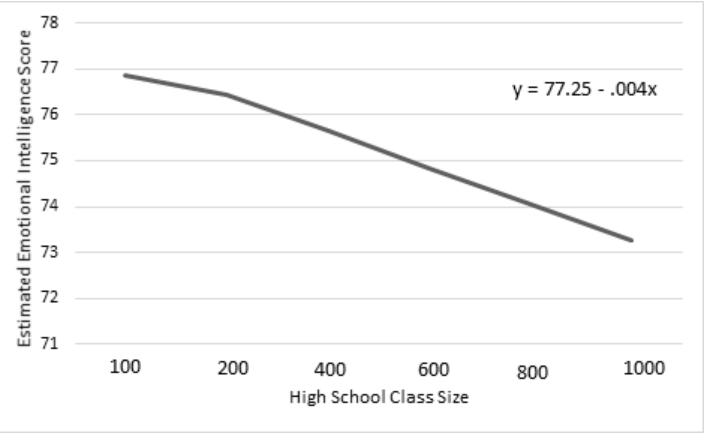

Figure 4. Emotional Intelligence score as predicted by high school graduation class size.

This result may indicate that students from smaller schools may be able to form closer bonds with their fellow students due to a variety of factors; previous classes together at the grade school level, more able to be team mates on sports teams due to lesser competition, a closer relationship in the local community, etc.

Other areas that were examined are listed in Table 3 below. In each of these areas, the sample size was either too small to produce findings, or the survey form was not clearly understood by the students and not completed properly.

The data did generally indicate that Electrical and Computer Engineering students have different EI Score values than Civil and

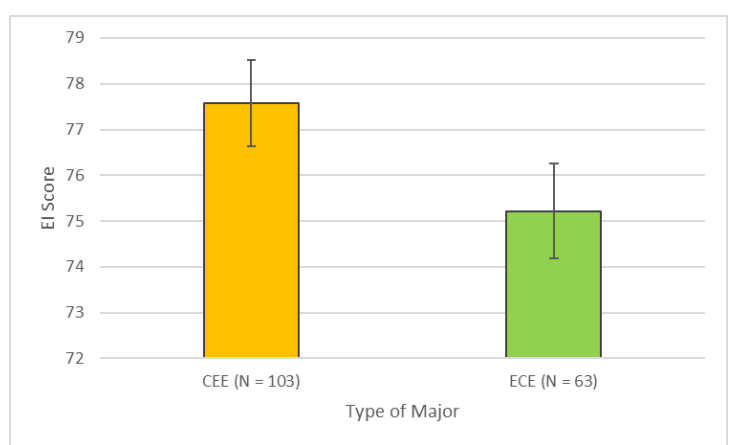

Figure 5. Emotional Intelligence score by undergraduate major.

Envirornmental Engineering students (Figure $5)$.

Additionally, the data indicates that Electrical and Computer Engineering students may not progress in the growth of their EI scores as well as their Civil and Environmental Engineering student counterparts, especially when year in school is considered. A factorial analysis of variance was conducted examining EI scores

\begin{tabular}{|l|}
\hline $\begin{array}{l}\text { Full Time Work Experience, 40 Hours/week (\# } \\
\text { months) }\end{array}$ \\
\hline Junior ROTC in High School? \\
\hline Level of Education of Parents? \\
\hline Parent served in military? \\
\hline \# Elementary Schools attended? \\
\hline \# Middle Schools attended? \\
\hline \# Different towns /cities lived in prior to college? \\
\hline Population of town/city you are from? \\
\hline Seasons of Junior Varsity sports played? Captain? \\
\hline Seasons of varsity sports played? Captain? \\
\hline Will pursue military career upon graduation? \\
\hline Volunteer Activities while in High School? \\
\hline Non Athletic Clubs in HS? \\
\hline Summer Jobs/Internships while in college? \\
\hline Athletic Teams while in college? \\
\hline
\end{tabular}

Table 3. Additional Survey Questions 
when considering student major and year in school. A main effect for the type of major indicated that $\mathrm{CEE}$ students have higher EI scores than ECE students, $\mathrm{F}(1,170)=2.85$, $\mathrm{P}=.09, \eta \mathrm{p} 2=.02$. A significant interaction showed that the EI scores of CEE students increase more over time when compared to ECE students, $F(1,162)=3.28, p=.07, \eta_{\mathrm{p}}{ }^{2}=$ .02 (Figure 6).

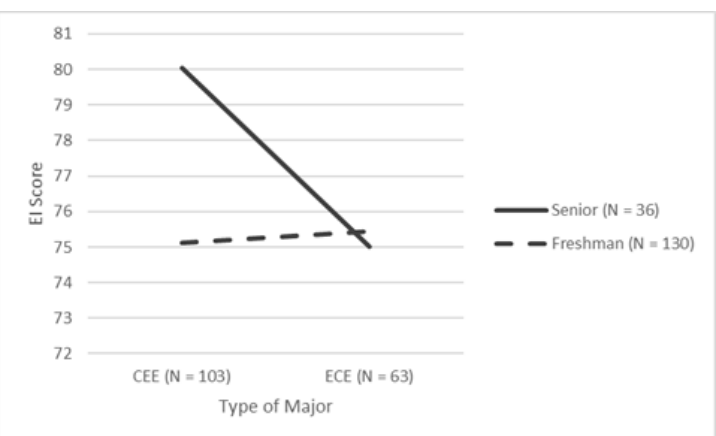

Figure 6. Emotional Intelligence changes, Freshman to Senior Year.

These results come with some caveats since the sample of ECE students that are seniors is small (70 students, only 19 of these seniors). Also it must be undertood that we do not know the EI scores of the Freshmen ECE students who departed the major before their senior year. It is recommeded that other researchers who have access to larger populations of engineering undergraduate students explore that area.

\section{Conclusions}

The purpose of this research was two-fold; first to determine if there was a difference between the EI scores of Civil and Environmental Engineering (CEE) students and Electrical and Computer Engineering (ECE) students, as measured by The TalentSmart Emotional Intelligence Appraisal@. Second, to determine if there were life influences that impact the differences in the EI scores. Due to small sample size of senior Electrical and Computer Engineering (ECE) Students, the portion of the analysis that identifies differences at the senior level from Civil and Environmental Engineering (CEE) students must be viewed with caveats. A much larger sample size must be used to produce definitive findings. However, the data does indicate that EI scores improved with age, and this applies when CEE and ECE students are combined in the analysis.

The research also indicates that there are identifiable life influences that impact Emotional Intelligence scores. Certainly age tends to increase EI scores, of all majors. Yet students who had substantial work experience in part-time jobs developed higher EI scores than their peers who did not. This is logical since it is predictive that EI is developed by close exposure to other people. Likewise, those students who attended smaller high schools also showed higher EI scores. These results indicate the value of developing close relationships with a group of classmates in helping students mature and be better aware of their relationships. Students who do not have to work (or choose not to work), or who attend larger high schools, tend to have lower EI scores.

In a discipline where expectations to perform are high, engineering students may feel more pressure than the average undergraduate to succeed. There are many calls in the literature for Emotional Intelligence skills to be included in the curriculum. In the United States, in order to be accredited by the Accreditation Board for Engineering and Technology (ABET), engineering programs must demonstrate that their students attain, amongst other outcomes, an ability to function on multidisciplinary teams and an ability to communicate effectively (Kirsch, 2012). This would appear to make a case for the inclusion of Emotional Intelligence training and 
experiences in undergraduate engineering curriculum.

The push to integrate EI into the curriculum recognizes that having EI skills can help develop an individual into a successful leader or manager, which is highly desirable in a work environment. Therefore, focusing on increasing the EQ level of students in tertiary education can increase students' marketability after graduation (Saibani et al., 2012).

Engineering faces unique challenges in helping their students develop improved EI scores. Undergraduate engineering education remains very demanding, and the heavy course load is required by all schools to maintain the essential ABET (Accreditation Board for Engineering and Technology) accreditation. The demands of majoring in engineering certainly benefit students in the long run with more lucrative jobs than their peers in other majors. However, in the short run there is little free time available during college to focus on relationships or pleasure. The result is that some students majoring in engineering may transfer to a less demanding major that enables a more pleasant college experience. It is up to educators to find a way to fill this void, and inculcate a sense of teamwork and belonging.

The research implies that there may be ways for educators to "have your cake and eat it too" by continuing the robust technical problem solving education that Engineering is famous for, while also helping students develop leadership and emotional intelligence. Increased opportunities for students to work problems together in the classroom, while constantly changing teams, may be one way. More use of graded team homework assignments may be another. The literature provides several studies that report efforts that have been made to look into this area, and more work can be done in this area. In the work force few engineers of any discipline work in isolation, and developing team skills and EI sooner would be valuable.

\section{Recommendations}

The Accreditation Board for Engineering and Technology (ABET) has recognized the need for engineering students to learn more about leadership and to be able to interact better with the public and others in their profession. Placing more emphasis on soft skills such as leadership, emotional intelligence, and the role of engineers in society is being valued by professional organizations of Civil Engineering, Electrical Engineering, and other disciplines of the engineering field - as well as employers. This support should be demonstrated by discussing the highly prescriptive course loads and content of undergraduate engineering courses necessary to retain accreditation. Engineering Deans, Department Chairs, and individual faculty members can then adjust course content and educational approaches to better support the growth of EI in engineering students.

Many employers make summer jobs and co-op programs available to undergraduate and graduate engineering students. These programs provide that essential opportunity to students for them to develop real life work skills and emotional intelligence. These programs should continue and be enhanced, with an eye towards making it possible for students to also complete required courses and stay up with their classmates. This includes military training offered to, or mandatory for, ROTC students seeking Active Duty or Reserve military commissions. Students should not have to choose between sacrificing their desired major, graduating with their classmates, or meeting strict training/graduation requirements. This is an important area for industry - academic collaboration. 
This research did have a sample size of 166 total students, but as such it raised more questions than it answered. Although an extensive array of broad based questions were asked on the supplemental questionnaire, in most categories, the sample size was simply too small to generate a substantial number of findings. Surveys that are far more detailed, that can track the changes in EI score by individual student who sticks it out in (or leaves) engineering, and a more robust sample size, may offer more and better findings. This would enable the important area of gender and ethnicity comparisons to also be explored. Additionally, research into the type of experiential learning opportunities afforded in the curriculum, such as team projects, working groups, internships, etc. may enable comparisons into the effectiveness of various EI development approaches. The authors believe that further research can be quite revealing in a variety of areas, but that depends upon a far greater population size.

\section{Acknowledgement}

The authors extend their gratitude to TalentSmart for the provision and support of the Emotional Intelligence Appraisal.

\section{References}

American Society for Engineering Education. (2013). Transforming undergraduate education in engineering. Phase I: Synthesizing and Integrating Industry Perspectives. Retrieved April 24, 2014, from

https://www.asee.org/TUEE_PhaseI_WorkshopRep ort.pdf.

Bar-On, R., Maree, J.G., and Elias, M. J., Eds. (2007) Educating people to be emotionally intelligent. CT: Praeger Publishers.

Badger, B. (2002). What Makes A Great Manager, Engineering News Record, McGraw Hill, December $2,2002$.

Boyatzis, R. E. (2009). Competencies as a behavioral approach to emotional intelligence. Journal of
Management Development, 28(9), 749-770. doi:10.1108/02621710910987647

Bradberry, T. R. and Su, L.D. (2006). Ability-versus skill-based assessment of emotional intelligence. Psicothema 18, supl., 59-66.

Bradberry, T and Greaves, J. (2009). Emotional intelligence 2.0. TalentSmart.

Butler, C. J., \& Chinowsky, P. S. (2006). Emotional Intelligence and Leadership Behavior in Construction Executives. Journal of Management in Engineering, 22/3 119 - 125.

Butun, E., Erkin, H. C., \& Altintas, L. (2008). A new teamwork-based PBL problem design for electrical and electronic engineering education: a systems approach. International Journal of Electrical Engineering Education, 45(2), 110-120. doi:10.7227/IJEEE.45.2.3

Cain, K., \& Cocco, S. (2013). Leadership development through project based learning. Proceedings of the Canadian Engineering Education Association, 1-6. Retrieved from http://library.queensu.ca/ojs/index.php/PCEEA/artic le/view/4869

Clarke, N. (2010). Emotional Intelligence and Its Relationship to Transformational Leadership and Key Project Manager Competencies. Project Management Journal, Vol 41/2, 5 - 20.

Dym, C., Agogingo, A., Eris, O., Frey, D., \& Leifer, L. (2005). Engineering design thinking, teaching, and learning. Journal of Engineering Education, 94, 103120.

Goleman, D. (1995) Emotional intelligence: Why it can matter more than IQ. London: Bantam Publishing. ISBN 0553375067.

Goleman, D. (2006). Emotional intelligence. Bantam.

Goleman, D. (1998). Working with Emotional Intelligence, Bloomsbury Publishing, London.

Iannucci, B. and Mirabella, J. (2013). Emotional intelligence: Can it be predicted from academic success. Review of Management Innovation \& Creativity, 6(20), 88-95.

Jahangard, L., Haghighi, M., Bajoghli, H., Ahmadpanah, M., Ghaleiha, A., Zarrabian, M. K., \& Brand, S. (2012). Training emotional intelligence improves both emotional intelligence and depressive symptoms in inpatients with borderline personality disorder and depression. International Journal of Psychiatry in Clinical Practice, 16(3), 197-204. doi:10.3109/13651501.2012.687454

Kirsch, K. N. (2012). Communication in engineering: Developing a targeted course. (Unpublished dissertation). Gonzaga University, Washington. Lamb, F., Arlett, C., Dales, R., Ditchfield, B., \& Wakeham, W. (2010). Engineering graduates for industry. The Royal Academy of Engineering Report. 
The Engineering Project Organization Journal (August 2017) 7, 1

Retrieved

from

http://www.heacademy.ac.uk/assets/documents/subj

ects/engineering/graduates-for-industry.pdf

Lappalainen, P. (2009). Communication as part of the engineering skills set. European Journal of Engineering Education, 34(2), 123-129. doi:10.1080/03043790902752038

Leicht, R.M., Macht, G. A., Riley, D. R. \& Messner, J. I (2013). Emotional Intelligence Provides Indicators for Team Performance in an Engineering Course. Engineering Project Organization Journal, 3/1, 2-12

Lohmann, J. R., Rollins, H. A., \& Hoey, J.J. (2006). Defining, developing and assessing global competence in engineers. European Journal of Engineering Education, 31(1), 119-131. doi:10.1080/03043790500429906

Mayer, J.D., and Geher, G. (1996). Emotional intelligence and the identification of emotional intelligence. Intelligence, 22, 89-113.

Ming Chia, Y. (2005). Job offers of multi-national accounting firms: The effects of emotional intelligence, extra-curricular activities, and academic performance. Accounting Education, 14(1), 75-93. doi:10.1080/0693928042000229707

Mo, Y. Y., \& Dainty, A. R. J. (2007). Measuring and enhancing the emotional intelligence of construction management students: An empirical investigation. Journal for Education in the Built Environment2(1), 110-129.

Petrides, K., Frederickson, N., \& Furnham, A. (2004). The role of trait emotional intelligence in academic performance and deviant behavior at school. Personality and Individual Differences, 36(2), 277293. doi:10.1016/S0191-8869(03)00084-9

Saibani, N., Sabtu, M. I., Muhamad, N., Wahab, D. A., Sahari, J., \& Deros, B. M. (2012). Comparison of emotional intelligence scores among engineering students at different stages of an academic program.
Asian Social Science, 8(16), 88-96. doi:10.5539/ass.v8n16p88

Salovey, P. and Mayer, J. (1990). Emotionalintelligence. Imagination, Cognition and Personality, 9, 185-211.

Shelby, R., Ansari, F., \& Patten, E. (2013). Implementation of leadership and service learning in a first-year engineering course enhances professional skills. Journal of Engineering, 29(1), 1-14. Retrieved from http://www.ryanlshelby.com/uploads/1/9/8/6/19863 76/ijee2644_proofs_2013_ryanshelby.pdf

Skipper, C. O., \& Brandenburg, S. (2013). Emotional intelligence and academic performance of engineering students. Engineering Project Organization Journal, 3(1), 13-21. doi:10.1080/21573727.2012.738669

Sunindijo, R. Y., Hadikusumo, B. H. W., \& Ogunlana, S. (2007). Emotional intelligence and leadership styles in construction project management. Journal of Management in Engineering, 23 (4), 166-171.

TalentSmart (2011) Product Factsheet, available at http://www.talentsmart.com/media/uploads/pdfs/fact sheet/EI\%20Appraisal-Me\%20Fact\%20Sheet.pdf (accessed 21December 2012).

Thilmany, J. (2005). Another kind of smart. Mechanical Engineering-CIME, 127, 17.

Van Der Zee, K. , Thijs, M., \& Schakel, L. (2002). The relationship of emotional intelligence with academic intelligence and the Big Five. European Journal of Personality16, 103-125.

Walesh, Stuart G. (2012). Engineering Your Future, John Wiley and Sons, ISBN 978-0-470-90044-4.

Zhou, X. (2010). Asessment and analysis of emtional intelligence in engineering students. Clemson University. 